\title{
Free Parties and TeKnivals: Gift-Exchange and Participation on the Margins of the MARKet and the State. ${ }^{1}$
}

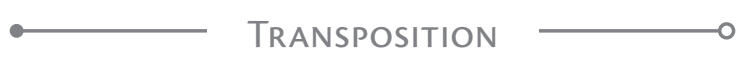

Anne Petiau

INSTITUte of Social Work ANd Social Studies (France)

Translation by Luis-Manuel Garcia

University of Groningen (Netherlands) and Max Planck Institute for Human DeVelopment (Germany)

\begin{abstract}
Through raves and then subsequently through "free parties" and "teknivals", French fans of electronic music have developed festive practices at the margins of the market and the state. In France, these events-especially so-called free parties-are often associated with free-access events or inversely with settings for parallel economies. And yet, these parties operate under a logic of gift-exchange, playing on its symbolic dimensions. The free party is experienced as a collective production, in the sense that the organizers of these sound systems expect an investment, an active participation from the audience, and also in that the participants, faced with the party-as-gift made by these collectives, are drawn into an obligation to contribute to the event in their own way. This participation can take the financial form of a donation, but can also be made by helping to set up or clean the event location, enlivening the festive space through spectacular street-theater, and also simply by dancing. This organization through gift-exchange is thus directly connected to the kind of participatory experience sought by the audience. The party-as-gift also prompts other collectives to offer their own festive gifts in turn; this entails a degree of emulation between sound systems. They acquire prestige and renown within this social world according to their capacity to provide both music and parties as gifts. ${ }^{2}$ A reading in terms of the gift makes it possible to capture how the pleasures of giving and spontaneity can coexist with economic interests and prestige.
\end{abstract}

KEYWORDS: free party, teknival, gift-exchange, participation, amateur practices, marginality

After completing a $\mathrm{PhD}$ in sociology on electronic music ("Musiques et musiciens électroniques. Contribution à une sociologie des musiques populaires”. University of Paris 5, 2006), AnNe PeTiau has conducted research in the fields of youth, cultural marginality and deviance. Her most recent work engages with youth cultures, digital practices and squatting, leading to the publication of two books (Technomedia. Jeunes, musique et blogosphere, éditions Mélanie Séteun, 2011; Vivre en squat. Une bohème populaire au XXIème siècle, éditions du CNRS, 2014). She is currently an instructor and research coordinator at the Institute of Social Work and Social Studies (ITSRS) as well as a research fellow at the Interdisciplinary Laboratory for Economic Sociology (LISE), which is associated with the National Conservatory of Arts and Design (CNAM) and the National Centre of Scientific Research (CNRS).

Dancecult: Journal of Electronic Dance Music Culture 7(1): 116-128

ISSN 1947-5403 @2015 Dancecult http://dj.dancecult.net

http://dx.doi.org/10.12801/1947-5403.2015.07.01.06

desncecult 
Translator's introduction: Anne Petiau's essay provides an analysis of the many dimensions of participation [to participate, but also to contribute materially] in France's "free parties" and "teknivals". Working both historically and ethnographically, she develops this analysis using the theoretical framework of reciprocal gift-exchange, first conceptualized in The Gift [Le Don] by Marcel Mauss (1997 [1950]) but also further developed by noted French anthropologists Alain Caillé (2000) and Jacques T. Godbout (2000). Petiau notes that free parties are understood by organizers and attendees to be "free" in both senses of the term-freedom [liberté] as well as "for free" [gratuité] while nonetheless relying on various forms of financial and in-kind donations from attendees. Notably, the free party itself is characterized by organizers as a gift offered freely to participants. And yet, as studies of gift-exchange suggest, gifts come with "strings attached", with obligations and expectations of reciprocity. And so, Petiau argues that participants' donations may not be as optional and freely given as they seem, illustrating how the actors involved in free parties articulate these expectations while reconciling them with the open-access ethos of these events. In addition to this insightful analysis, the essay provides a useful introduction both to the French free party/teknival scene as well as to the anthropology of gift-exchange. Anne Petiau's article first appeared in French in 2012 as "Free-parties et teknivals. Dans les marges du marché et de l'Etat, système de don et participation", in Festivals, raves parties, free parties. Histoire des rencontres musicales en France et à l'étranger, N. Bénard (ed.), 587-610. Paris: Camion Blanc.

At first through raves and then "free parties" and "teknivals", electronic music has developed at the margins of the professionalized and institutionalized networks of music and live spectacle. ${ }^{3}$ This preference for alternative (read: clandestine) practices is one way that fans can avoid the administrative, legislative and financial constraints that hinder the development of activities and the organization of festive events. Also at stake in keeping oneself on the margins of institutionalized networks is the ability to develop logics foreign to both the market and the state. Free parties-and to a lesser degree raves-operate under a logic of gift-exchange, playing on its symbolic dimensions. This approach offers a perspective on the diverse practices in these festive spaces, ranging from the principle of donation that prevails over access to parties up to and including the ordinary sociability of participants.

\section{Alternative Electronic Festivities: From Raves to Free Parties}

In England, raves emerged as a result of new regulations passed by the Thatcher regime in 1988, forcing London clubs to close at two o'clock in the morning. Wild parties were organized in the countryside or in suburban warehouses; these warehouse parties and later acid parties grew explosively to the sound of house music (Garnier and Brun-Lambert 2003: 28-29, 55). In France, despite the different legal context, the principle of organizing parties outside of venues intended for such purposes began to gain currency. Even if promoters, concert halls and nightclubs did not hesitate to convert themselves to these new sounds, 
the emancipation from sites dedicated to music events gave rise to a new festive format: the "rave" party. This created an opening for fans and amateur event-promoters, who could thereafter organize parties outside of conventional venues and without observing applicable laws, thus simplifying matters to a great extent. Thus, along with larger events organized by professionals came a proliferation of more or less large-scale raves, often clandestine and semi-legal, ${ }^{4}$ organized by amateurs in varying degrees of formal association. One accelerating factor in the development of raves was in fact its growing repression. In the middle of the 1990s, it became very difficult for individuals and amateurs to organize a rave party in France. Requests for permits were almost always refused when electronic music was involved. Police interventions become more frequent, based on the recommendations of a 1995 inter-ministerial circular. ${ }^{5}$ The intensifying repression of raves together with the near-systematic refusal of permits served to make completely clandestine operations the more attractive choice, thus contributing to the growing development of "free parties", also inspired by developments in England. At the end of the 1980s, the world of UK "new age travellers" (Delorme 2001: 107-123) came into contact with the acid party scene, which was experiencing explosive growth at the time. Some of these travellers converted to these new sounds; equipped with sound systems, they punctuated their movements with the organization of parties. The repression of Prime Minister Margaret Thatcher and her government pushed some of them to emigrate to France-notably Spiral Tribe, ${ }^{6}$ under the threat of a conviction against them in England. Thus was the "free party model" imported into France at the beginning of the 1990s where, following the example of the English tribes, sound systems such as les Teknocrates, les Nomades, les Psychiatrik and d'OQP were establishing themselves. "Teknivals", gigantic techno-festivals open to any sound system that wanted to play their music, also made an appearance (Grynszpan 1999: 25-26, 38). With the second inter-ministerial circular of 1998, the repression of free parties hardened, ${ }^{7}$ finally crystalizing in 2002, when a public-safety law came into effect, targeting "certain festive gatherings with a musical character". This mandated that the organization of a free party be declared in advance, which could then be prohibited if the venue does not fulfill legal requirements, while also sanctioning the seizure of sound equipment, the levying of fines, and legal action in the case of a failure to declare or the violation of an injunction. This new legal context together with numerous seizures of sound equipment halted the development of free parties. They did not disappear entirely, in any case, but they have become more discreet. Negotiations between organizers and local authorities allowed for teknivals to take place legally. ${ }^{8}$ Some of these-such as one in Chambley in May of 2004attracted a crowd of up to 80,000. Between 2003 and 2013, both legal and illegal teknivals were organized, with some clandestine events followed by seizures of sound equipment, such as occurred at the teknival at Bouafles in 2009 and at Saint-Martin de Crau in 2011 (Kosmicki 2010: 654-670).

The transition from raves to free parties can be seen on several fronts as the radicalization of the principles adopted by raves. On the one hand, there was a radicalization in terms of their relation to the law, since they ignored the legal contingencies of organizing live 
events. Free parties, which managed themselves financially as well as technically and artistically, eliminated the remuneration of employees and the need for professionals. They also eliminated admission fees, in favor of a principle of voluntary donation. Participants were thus not required to provide a fixed entrance fee, but rather were invited to make a contribution-financial or material - to the organizing collective. On the other hand, free parties radicalized the organizational form of collectives. These involved an affective investment and a larger staff, since their members often collectively owned the sound equipment that enabled amplified music playback-sometimes along with the bus or truck necessary for its transportation-at times even living together as a commune. And finally, free parties radicalized musical and artistic expression.

Raves opened up a marginal position for a time, where actors developed events in parallel to professionalized musical and festive milieus-at least until some of these protagonists became professionals in turn. The return to clandestine and amateur operations achieved by free parties reopened this marginal position. Once again, actors bypassed judiciary structures, avoiding administrative, legislative and financial obstacles. Once again, they invented ways of being together, spaces of congregation, and mechanisms of sonic transmission. In this sense, one could see the historical transition from raves to free parties as a reopening of participative space. Respecting the legislative framework for live entertainment entails expenses (e.g., venue rental, security, licensing fees to the performing rights organization SACEM), and the establishment of a parallel network for music and parties provides a means of engaging in musical and organizational activities while avoiding the constraints that would otherwise limit access to these activities. At the same time, since they avoided professional networks, since they avoided recourse to state institutions and freed themselves of their regulations and, in short, since they developed on the margins of the market and the state, these young actors were able to develop practices in relation to different logics. In these alternative festive practices, one can recognize the means by which individuals constantly reestablish social ties relevant to a system of gift-exchange, whether outside the systems of market and state or in their interstices (Godbout 2000 [1992]: 235, 237).

\section{The Donation Principle}

For participants, a "free party" is free in every sense of the term. Exploiting the double meaning of "free" in English, they refer both to the freedom of action within these events as well as their free-of-charge admission [gratuité]. In reality, however, free parties are based on a donation principle, and a donation is not "for free",per se. As Mauss has demonstrated (1997: 143-279), the gift is a system composed of giving, receiving and reciprocation, entailing elements of obligation and interest. At a free party, in fact, donation takes on an obligatory character; obligation exists in the sense that failing to make a donation is frowned upon, while the donation itself-even a specific level of donation-may be demanded.

Bertrand: Certainly, if someone arrives to the entrance in a BMW, an Audi, or even a nicely polished [Peugeot] 405, five guys sitting inside wearing fifteen hundred francs 
worth of clothing, and they want to give a donation of only five francs each, you tell them, "Guys, please, make an effort; we're busting our ass for you, so do something now or help us out." So, it sometimes happens that we're a bit blunt with people like that, with the obvious slackers, but we appreciate the work of all of those people who show goodwill and come to lend a hand.

Free parties are nonetheless defined by their free admission, as much by the collectives that value offering the party-as-gift as by the participants who value contributing to a freeof-charge party. Here one can recognize the "rule of the implicit" that is characteristic of systems of reciprocal gift-exchange, where "there is no ignorance, but rather an active and conscious refusal by both parties to be explicit, a double and symmetrical hypocrisy, thus normally absurd and pointless. And furthermore: not only does one refuse to make the rules explicit, one seems to wish to articulate other ones that affirm the opposite of what happens 'in reality'. One affirms the absence of an expectation of reciprocity, all the while expecting the gift to be returned. One proclaims gift-giving while being engaged in reciprocity" (Godbout 2000 [1992]: 262-3). The printing of the abbreviation "PAF" [participer aux frais: contribute to expenses] on rave flyers was characteristic of this tension in relation to the gift, in the sense that it was an invitation to contribute [participer] to defraying the costs of the party rather than paying a fee in order to attend. At free parties, partygoers are invited to "participate" in the defraying of expenses, but the rule remains implicit.

A donation in the form of a financial contribution is only one mode of counter-gift among many: participants can also donate cigarettes, hash, gas, etc. Besides, the party-as-gift calls for participation in a more general sense: helping to set up or clean the event location, enlivening the festive space through spectacular street theater, and also simply by dancing. After all, what's the use in "giving" a party if the participants don't fulfill it through dance?

Olivier: It's that there's really lots of energy for making things and offering things to people. Maybe offering things to people is a way of nourishing one's own ego, but still, there are people who dance, people who juggle, for our viewing pleasure... I mean to say that, regardless of what you do, it's also for the crowd; you also offer it to the crowd. I mean to say that even just one person dancing to the music, you'll always have someone who will dig it, who'll say, "Oh yeah, his dancing cracks me up," or something. So, there's this kind of exchange between the people who dance, also the people who sell-because there's a lot of business, as much for water as for drugs and beer, sandwiches and all that-but everyone offers their little thing that makes things work. And, without one or the other, it won't work. To begin with, the sound systems [collectives] give their sound to the crowd for free, without anyone having to do anything; you're not buying a ticket so that you can watch. Ultimately, that's really the free-party spirit, that's what's beautiful about it and that's what we all love about it. It's the fact that there are people who give this, and considering that it's the people who organize (so to speak) who are giving this, well then the people who received it are also obliged to give a minimum amount. 
The rule of gift-exchange, if it functions implicitly in actu, is clearly formulated here. Faced with the party-as-gift offered by these collectives, participants are also prompted to contribute to the maintenance of the festive event. The party's financial, artistic and technical self-management implies that all help is welcome, and that it can take multiple forms.

Jeremy: You have some guys with vans, and what do they do? Well, they'll park their vans all around, making a dance floor. I mean, if there weren't any vans, there wouldn't be a dance floor, so there you go. I mean, with the means that we have, we couldn't do otherwise, in any case. They're even helping us out, really. ${ }^{9}$ And as for what we bring, well I'll tell you that we're just an "engine", but still, when you stick an engine in a car with no wheels, no steering wheel, no whatever, you're not going anywhere. So, that's what I like about it.

Free parties are experienced as a collective production, in the sense that the sound systems expect an investment, an active contribution [Fr.participation] from the audience, and also in the sense that the participants, faced with the collective's party-as-gift, are drawn into the obligation to contribute to the collective event in their own fashion. Both groups derive pleasure from their engagement in this system of gift-exchange: for the former, pleasure in giving the party-as-gift, and for the latter, pleasure in making a contribution to it.

This participatory dimension and the importance of mutual aid are both emphasized by certain ravers as well, which is notably the case in parties devoted to the "psytrance" genre of electronic music. These sometimes offer free admission when they are held in developing and emerging nations (India, Thailand, South Africa, etc.), and the participants can contribute to the party not only by dancing, but also by performing amusements of various sorts (juggling, fire-dancing, decoration) and providing support in organizational tasks. ${ }^{10}$ At the largest of festivals, which charge an admission fee but take place outdoors (Europe during the summer season, the southern hemisphere during the European winter), participants also find a liberty of movement and a participatory dimension that they deem to be absent from more traditional party venues such as clubs.

Jocelyn: For me, an ideal trance party would be one where people will look after and help each other; that's a part of the pleasure. Yesterday afternoon, I was bored at the party because it was the afternoon and there's nobody around at that time, so I instinctively started helping the organizers, who were having trouble, and I got a great deal out of it, personally. I completely understand why Mother Theresa dedicated her life to helping others. That's present at an ideal party, this desire to help one another... There are lots of people who offer to help with the decoration, and such.

Participants and collectives thus highlight the importance of mutual aid within the festive space. In a particular way, this involves "giving back", contributing in one's own way to the party's fulfillment, even if one is giving back to others. 
Jeremy: There's also the problem of trash. If you manage to raise awareness about it, and if in the morning you get there and you see big heaps of garbage bags neatly arranged, well then, you're happy. What's more, you see, that means people really wanted to contribute [Fr. participer], and that's also what lends a bit of magic to the free party, since everyone lends a hand; it'll be the bottle of water you give to some guy, a bandage you give to someone else. Everyone helps each other out that way, it's autonomous. And there you go, that's a good free party to me.

Ultimately, the "ideal" free party as it is represented by actors—an ideal rarely reached, to be sure, and just as mythical and real as collective effervescence-would achieve the "total reciprocity" described by Mauss, where the entanglement of (direct, indirect, alternating, delayed) reciprocities would engender mutual engagement while also bringing the group itself into being (cited in Papilloud 2002: 96).

Not all participants are sensitized to this participatory dimension, which operates in the symbolic register. Various modes of engagement exist within the party, whether it be rave or free party. Participatory experience and the experience of festive effervescence are two distinct modalities, two aspects of the party's lived experience. Some participants come simply in search of collective musical experience, the loss of self on the dancefloor, as well as a moment of conviviality. Free parties thus gain much of their attractiveness from the breadth of the festive rupture that they generate. Some seek both of these dimensions, each reinforcing the other. If it is ultimately the members of the organizing sound systems who address this theme most directly, it is undoubtedly because they have been sensitized to this dimension, the participatory experience of partying having led to giving one's own party-asgift in turn. Indeed, Lionel Pourtau (2009: 61-2) emphasizes that putting together a sound system and throwing a party are ways of paying back the debt of initiation in a transitive manner; we return to others the fact of having been initiated ourselves. This manifests as a contemporary mode of gift-exchange, in that it is turned towards strangers.

\section{System of Gift-Exchange or Parallel Economy?}

Commercial exchanges take place at the heart of the free party: the sale of records, cassettes, clothing, drinks, food and drugs. Donations, drink stalls and stands all represent a source of revenue for organizing sound systems. These exchanges constitute a parallel economy, since they escape taxation by the state (Grynszpan 1998: 28-30). For some authors, the affirmation and demand of free admission to free parties merely functions to mask the real interests of the actors and to obfuscate the circulation of money (Liogier 2004: 143-4):

Defacto, the practice of donation provides a glimpse of how the party is a zone ruled by both commercial and non-commercial exchanges. In fact, this generous contribution by each and every one appears in reality to be a tithe. The participant is not free to give whatever he likes, despite the organizers claims to the contrary. In this way, the latter make use of a symbolic act of giving (the gift of oneself, participation) in order to force the individual to obey an obligatory practice of the commercial order. Not 
offering any money-or offering too little-exposes one to forceful expulsion from the party (sometimes including physical brutality). The average donation amounts to around 20 francs. If one cannot contribute money, the individual is called upon to donate cigarettes, a piece of hashish or something else. The exchange thus becomes non-commercial and the financial profit is replaced by payment in-kind. Here, the gift hides lucrative activities (Queudrus 2000: 27).

It seems difficult to concede that organizing collectives would have financial gain as their primary goal in throwing a party. If this were the case, one might justifiably ask, on the one hand, why they organize parties instead of simply engaging in clandestine activities, and on the other hand, why they resort to the language of gift-exchange and free-of-charge participation. It would also seem much simpler, if indeed they had nothing more than lucrative activity in mind, to substitute the donation principle with a fixed admission fee. It should be noted that Queudrus enumerates in fact all of the characteristics of the gift: its characterization as free in theory but obligatory in reality (to paraphrase Marcel Mauss); monetary non-equivalence; the "rule of the implicit and unsaid", where one proclaims rules that diverge from what actually happens; the entanglement among participants of disinterest and interest. As Godbout notes, "If modernity refuses to believe in the existence of the gift, it is because it represents the gift as the inverse of egoistic material interest. In their eyes, a 'real' gift could only be free of costs [gratuit]. And since freedom from cost [gratuité] is impossible [...], the gift, the real gift, is just as impossible" (Godbout 2000 [1992]: 14). This approach evacuates the specificity of the donation and the importance of the notions of gift and freedom from charge [gratuité] for actors, as well as the significance that these actors ascribe to their practices. And yet, the pursuit of material interest or prestige is not incompatible with gift-exchange. In fact, it is precisely in the gift itself that the pursuit of such interests, generosity, spontaneity and the pleasure of giving mix together (Caillé 2000: 126).

One could risk making a comparison and say that, somewhat like the kula, ${ }^{11}$ these commercial exchanges take place at the margins of the gift-exchange. Mauss attests that commercial exchanges are indeed carried out in parallel to the ceremonial exchanges of the Trobriand Islands. The maritime voyages organized in connection with the kula can also be an opportunity to carry out commercial exchanges, but these are carefully distinguished from the ceremonial exchanges, which are the only ones considered "noble" (Mauss 1997: 176). In a way, these commercial exchanges are also contained within the margins of the free party, since they do not affect the donation principle that governs access to parties. In other words, the presence of commercial exchange does not affect the symbolic dimension of the gift. The free party is experienced as a party-as-gift by both collectives and participants, even if commercial exchanges take place within. And, like in the case of the kula, it is those exchanges operating under a logic of gift-exchange that are considered the most noble.

For a few, free parties are undoubtedly an ideal context for conducting remunerative practices that are illegal or part of a parallel economy. It seems nonetheless simplistic to 
reduce the entirety of the free party down to a space conducive to the development of remunerative activities, thus rendering abstract the passionate dimension claimed by participants while also ignoring the specificity of the donation principle along with its concomitant participatory dimension.

\section{Where Giving Becomes Virtue}

At the heart of the free party, the capacity to give comes to be established as a virtue. In part, this governs ordinary sociability: both sharing one's food, drinks, drugs and offering one's (mechanical, technical, etc.) expertise constitute a well-appreciated behavior in this festive space. For collectives and musicians, this also has to do with knowing how to "give" a party and music. If the party-as-gift prompts one and all to participate in the collective event, it also prompts other collectives to make a gift of their parties in turn. There is a certain degree of emulation between sound systems. The principles of honor and competition identified by Mauss in the potlatch ${ }^{12}$ find expression to a certain degree in the free party. The goal here is not to establish the equivalence of two social phenomena so culturally estranged as potlatches and free parties. We should recall that, for Mauss, the potlatch represented an exemplary expression of the system of gift-exchange, in that certain elements are "exaggerated" (to use his phrasing) and thus more intelligible (Mauss 1997: 209-212). In fact, the party-as-gift given by a collective functions like a provocation, in the sense that it challenges other collectives to offer their own party-as-gift in turn as well as to do it better and to give more, whenever possible. This challenge incites some collectives to greater and greater logistical feats in the organization of their parties, within the limits of their resources: enormous walls of sound, certainly, but also light shows, lasers and decorations. This orgy of expenditure elicits admiration, but also at times critique ("throwing away cash to have a techno Disneyland", as one participant puts it in a discussion forum on the Internet), ${ }^{13}$ seeing in it a spectacularization far afield from initial ideals.

Collectives garner prestige and renown within this social world according to their capacity to provide both parties and music as gifts (see also Pourtau 2009: 158). One should also note that some among them see a deviation from their ideals in the accumulation of renown and prestige through the party-as-gift. In their eyes, the only motivation for organizing a partyas-gift should be "to advance the movement", that is, to give without any interest other than contributing to the festive phenomenon of free parties. Furthermore, the prestige attached to tribes and sound systems appear to them to contradict the principles of free access and anonymity that they endorse.

Olivier: I think that techno did not originally mean, "Ooh, Spiral Tribe! Ah les Teknokrates! Oh, les THC..." ${ }^{14}$ In the beginning we fought against that, I think. But unfortunately people need to go, "Oh, the DJ!" "Ah, they're better than them", presumably because they prefer the sound of one or the other. As a result, you're less connected to the festive side and the message that it delivers. There is always this contradictory element in all things; we want lots of things but at the same time we 
are no less attached to our social values, our culture, our upbringing, and capitalism itself, which tells you, "You must be better than others". It's a milieu that is really so contradictory that it's difficult to achieve anything, in the end.

If the gift is to be held up as a virtue, it must be completely disinterested for its actors. And yet, as we have already seen, the gift is always torn between two poles, pulled along two axes: on the one hand, that of disinterest and interest and, on the other, that of freedom and constraint (Caillé 2000). Incontestably_and despite the fact that certain actors would like it to be otherwise, in order to preserve the ideal of purity that enfolds the notions of gift and free access in our society, which seem to be completely opposed to notions of interest and profit-the party-as-gift and the gift of music also generate social superiority and contribute to the development of social hierarchy. But if presenting oneself as generous incontestably "reaps rewards" in these terms, the criticisms generated when certain collectives gain fame and renown-which is deplored as a reproduction of the "star system" that they oppose, where the collective comes to play the role of the star-demonstrate that the gift cannot be reduced to the logics of interest and profit. In other words, there is also a certain pleasure to be found in giving the party-as-gift, a generosity which makes sense in itself.

\section{Self-Organisation, Gift-Exchange and Participation}

Both raves and free parties show us the self-organizing capacities of social groups-that is, their capacity to invent forms of collectivity, spaces of congregation and mechanisms of musical transmission-at the margins of institutions. Some authors have highlighted the pertinence of TAZ ("temporary autonomous zones") to understanding free parties (e.g., Grynszpan 1998: 30-1). Developed by Hakim Bey, this concept shares a certain genealogy with Maffesoli's "interstitial liberties" (1992: 85-98) and De Certeau's "arts of doing" (1990). What these authors have in common is the attention they give to the way in which popular categories and ordinary people react to the constraints of order instituted by practices of resistance, subversion, reappropriation and disappearance. Their focus of attention is displaced away from the institution and its modalities of imposing order towards the analysis of those procedures through which consumers and users either subvert products and spaces, turning passive consumption into active production, or invent for themselves spaces of autonomy and liberty within the interstices of the status quo (Dosse 2002). Individuals mobilize practices resistant to the logics of market and state, thus also avoiding being reduced to the roles of consumer of goods or user of services. At stake in this avoidance is the constitution of the subject itself (De Certeau 1990: 52-3).

The development of raves and free parties in the gaps of institutions, the resistance on the part of free party participants to professionalization as well as the legislative framework dictated by the state all serve as means for participants to preserve their complete investment in organization and musical practices. To clarify, it is not the intention here to mount a critique of the market and the state, but rather to grasp the stakes for actors involved in gathering together, undertaking and developing activities in an autonomous manner. This 
also enables these actors to deploy alternate logics. The party-as-gift, the gift of music, makes demands: it calls on each one to contribute and commit oneself to the collective event. The gift of oneself (of time, music, art) calls for reciprocity and, in festive contexts, takes the form of a contribution [Fr. participation]. Here we encounter the notion of the wager, consubstantial with the gift. The gift relies on the uncertainty of reciprocity; even though organizers reduce this by instituting a donation principle, the success of a party nonetheless depends on the goodwill of its participants-for example, for site cleanup and waste management. This participatory dimension constitutes one of the specificities of the festive experience of raves and free parties.

Raves and above all free parties operate to a certain degree under a logic of gift-exchange, playing on its symbolic dimensions. For Godbout, the gift represents a link: its efficacy lies in its capacity to engender relationality, to create social ties, and to make relations last (Godbout 2000: 244-247). To this definition we can now add that the gift also represents a form of participation.

Organization based on a system of gift-exchange has its limits. It should be noted that the wager made by organizers does not always pay off, especially when the parties elicit growing attendance. The growing enthusiasm for raves and free parties calls for the professionalization of organizers or state involvement in management. For example, the state's involvement in the organization of teknivals - which drew tens of thousands of attendees-has proven to be indispensible. Collective formation based on a system of gift-exchange also runs up against its limits in the multiple modalities of festive participation. Many attendees come simply to seek out trance, effervescence and conviviality, rather than participatory experience, which cannot bear any rupture between promoters and their audience.

\section{NOTES}

1 Original publication: Anne Petiau. 2012. "Free-parties et teknivals. Dans les marges du marché et de l'Etat, système de don et participation". In Festivals, raves parties, free parties. Histoire des rencontres musicales en France et à l'étranger, N. Bénard (ed.), 587-610. Paris: Camion Blanc.

2 [TRANSLATOR: It should be noted that, in French, one common expression for throwing a party, donner une fête, includes the verb donner [to give], which itself takes as its root the word for "gift" [le don]. This enables the author to more frequently and idiomatically cast the organization of a festive event as a gift. This word-choice cannot be retained in English without excessive awkwardness, and so variations on the expression "party-as-gift" will be used in its place, when this emphasis on gift-giving is contextually important.]

3 This article picks up on several conclusions from my thesis in sociology, "Musiques et musiciens électroniques. Contribution à une sociologie des musiques populaires [Music and electronic musicians. Contribution to a sociology of popular music]" (defended in 2006 at the University of Paris 5 under the supervision of Michel Maffesoli), for which a survey was conducted in conjunction with direct observation and comprehensive interviews with thirtyseven musicians and fans. Quotations from interviews included here have also been drawn from this thesis. 
4 That is, respecting certain conditions necessary for the organization of a live event. The organization of a live event requires the possession of an event-promoter's license. Individuals or associations can nonetheless organize up to six live events per year without a license [at the time of original publication, 2012], but only in accordance with applicable regulations, including: requesting a permit from city hall, declaring the event at the local police station, obtaining a temporary license to serve alcohol, requesting permission from SACEM [France's rights-management society for music] for the public playback of musical works registered in their catalogues as well as paying the corresponding licensing fees.

5 Entitled, "Raves, high-risk events", this memo lists infractions that agents of law-enforcement can mobilize in order to interrupt a party and pursue its organizers. It advocates refusing permit requests in cases that involve a rave party. For more on the history of French raves, see Fontaine and Fontana (1996) and Racine (2002).

6 [TR.: See also: St. John, Graham. 2009. Technomad: Global Raving Countercultures. London: Equinox Publishing Ltd.]

7 This distinguished between gatherings having obtained a permit and clandestine gatherings. It advocated accompanying the former and treating them along the lines of similar types of gatherings with regards to permit requests (the example given is that of rock concerts), provided that they fulfill all of the conditions stipulated by law; but it reiterated existing repressive orders towards the latter.

8 The first legal teknivals were nicknamed "Sarkovals", referencing the name of the Minister of the Interior at the time, Nicolas Sarkozy. These were followed by other authorized teknivals arising from negotiations with public authorities, followed in turn by a new event-concept called "Multisons," authorized at the district/regional level [départements].

9 Free parties take place in locations not normally dedicated to musical gatherings, and so the festive space is not delimited in the same manner as in a concert hall or a discothèque. Vans and trucks parked by participants can thus contribute to the delimitation of the dance floor.

10 Psytrance parties are generally not self-managed, however. In some cases, they are managed by local actors (for example, in Goa or on the southern islands of Thailand) who have found in western festive tourism the basis for a flourishing economy. The parties may offer free admission, but the organizers can, for example, reap substantial profits from the bar, where prices are up to ten times more expensive than local standards. Other parties and festivals are organized by promoters (in South Africa, Portugal, France, etc.), charging admission fees that can sometimes be quite high.

11 The kula is a system of tribal and inter-tribal gift-exchange of symbolic goods, practiced by the inhabitants of the Trobriand Islands and New Guinea. This was studied by B. Malinowski in Argonauts of the Western Pacific (1922), to which Mauss refers (1997).

12 Potlatch is a gift-exchange system practiced in numerous ancient societies, notably indigenous tribes of the American Northwest. Potlatch has a festive dimension, but also religious, economic and political ones. It is notable for its agonistic character: in the course of ceremonies, goods may be not only given but destroyed.

13 See: <http://3boom.net $>$.

14 Sound systems that have organized free parties. 


\section{REFERENCES}

Bataille, Georges. 1995. La part maudite. Paris: Les Editions de Minuit.

Bey, Hakim. 2000. TAZ: Zone autonome temporaire. Paris: Editions de l'Eclat.

Caille, Alain. 2000 Anthropologie du don: Le tiers paradigme. Paris: Desclée de Brouwer.

- - . 2003. Critique de la raison utilitaire. Manifeste du MAUSS. Paris: La Découverte.

De Certeau, Michel. 1990. L'invention du quotidien. Vol. 1: Arts de Faire. Paris: Gallimard.

Delorme, Annick. 2001. "Les new Age travellers: Une tentative d'individualisation dans la société du risque". Sociétés 72: 107-23.

Dosse, François. 2002. "L'art du détournement: Michel de Certeau entre stratégies et tactiques". Esprit 283.

Douglas, Mary. 2004. "Il n'y a pas de don gratuit". In Comment pensent les institutions. Paris: La Découverte.

Fontaine, Astrid and Caroline Fontana. 1996. Raver. Paris: Economica.

Garnier, Laurent and David Brun-Lambert. 2003. Electrochoc. Paris: Flammarion.

Gauthier, François. 2001. "Consumation: La religiosité des raves”. Religiologiques 24: 175-200.

Godbout, Jacques T. (with Alain Caillé). 2000. L'esprit du don. Paris: La Découverte.

Godbout, Jacques T. 2000. Le don, la dette et l'identité: Homo donator vs homo xeconomicus. Paris: La Découverte.

Grynzspan, Emmanuel. 1990. Bruyante techno: Réflexion sur le son de la free party. Nantes: Mélanie Séteun.

Guibert, Gérôme. 2005. "Les musiques populaires: Commerce, loisir, underground ou tierssecteur?"Lesc@hiersdepsychologie politique 7.

Liogier, Raphaël. 2004. "Entre marginalité magnifiée et récupération 'postindustrielle' ”. Autrement 231: 141-158.

Lourau, René. 1969. L'instituant contre l'institué. Paris: Anthropos.

Kosmicki, Guillaume. 2010. Free party. Une histoire, des histoires. Paris: Les mots et le reste.

Maffesoli, Michel. La transfiguration du politique. Paris: Grasset et Fasquelle.

Mauss, Marcel. 1997 [1950]. Sociologie et anthropologie. Paris: PUF.

Papilloud, Christian. 2002. Le don de relation: Georg Simmel - Marcel Mauss. Paris: L'Harmattan.

Petiau, Anne. 2006. “Marginalité et musiques électroniques”. Agora Débats/Jeunesses 42: 128-139.

Petiau, Anne. 2004. "L'expérience techno, des raves aux free parties". In special issue, "La fête techno. Tout seul et tous ensemble", ed. Béatrice Mabilon-Bonfils. Autrement 231: 28-42.

Pourtau, Lionel. 2009. Techno: Voyage au cour des nouvelles communautés festives. Paris: CNRS Editions.

Pourtau, Lionel. 2005. "Les interactions entre raves et législations censées les contrôler". Déviance et société 29(2): 127-139.

Queudrus, Sandy. 2000. Un maquis techno: Modes d'engagement et pratiques sociales dans la freeparty. Nantes: Mélanie Séteun.

Racine, Etienne. 2002. Le phénomène techno: Clubs, raves, free-parties. Paris: Imago. 